\title{
Analysis of Morphological changes in the Gold Coast Seaway
}

\author{
M.Sedigh ${ }^{1}$, R.Tomlinson ${ }^{2}$, A. Golshani ${ }^{2}$, Nick Cartwright ${ }^{3}$ \\ ${ }^{1}$ School of Engineering \& Griffith Centre for Coastal Management, Griffith \\ University \\ Gold Coast Campus, Qld 4222, AUSTRALIA, (+61)755527608, \\ m.sedigh@griffith.edu.au \\ ${ }^{2}$ Griffith Centre for Coastal Management, Griffith University \\ Gold Coast Campus, Qld 4222, AUSTRALIA, r.tomlinson@griffith.edu.au (+61)7 \\ 55528499, a.golshani@griffith.edu.au (+61)7 55528449 \\ ${ }^{3}$ Griffith School of Engineering, Griffith University, Gold Coast Campus, Qld 4222, \\ AUSTRALIA, (+61)755529214 n.cartwright@griffith.edu.au
}

\begin{abstract}
Historical bathymetric data is being collated to map out the trends of morphological changes and ebb-delta growth at the Nerang River entrance which is also known as the Gold Coast Seaway after construction of entrance stabilisation works in 1985. The influences of various environmental and anthropogenic drivers which have impacted on the entrance morphology are investigated using available historical bathymetry, wave, dredging and bypassing data.
\end{abstract}

\section{Introduction}

The Gold Coast Seaway is located on the Australian East coast at a longitude of $27^{\circ} 56^{\prime} 10 \mathrm{~S}$ and a latitude of $153^{\circ} 25^{\prime} 60 \mathrm{E}$ and links an intra-coastal waterway known as The Broadwater with the Pacific Ocean. The Seaway was created when a natural inlet (the Nerang River Entrance) was stabilised in 1986. In the case of Gold Coast Seaway and many other waterways that have channel infilling problems and navigation issues it is crucial to understand the dynamics of the waterways and different variables that affect its morphology.

After construction of the Seaway, although there has been a bypassing system, the growth of the ebb-tidal delta was still one of the main concerns. There have a number of studies that have examined hydrodynamics in the vicinity of the Gold Coast Seaway (eg. Mirfenderesk and Tomlinson, 2008). Moreover, a number of studies have also been carried out on the different factors that influence the morphological changes in the Seaway area and growth of delta (Chapman, 1981; D'Agata and 
Tomlinson, 2004; Delft, 1970; Delft, 1976; McCauley, 1997; Munday, 1995; Patterson, 2007; Polglase, 1987; Sennes et al., 2007; Voisey, 2004; WRL and GCCM, 1998), but the dynamics of the Seaway and the development of the ebb-tidal delta are still poorly understood.

\section{Different drivers that influence Gold Coast region morphology}

\section{Wave Climate}

The Gold Coast Seaway is exposed to several wave conditions during the year. The wave climatology of the Gold Coast can be subdivided into four main categories: Ground swell (GS), wind swell or local wind seas (WS), East Coast Lows (ECL), and tropical cyclones (TC). Ground swell is the dominant offshore wave climate and is typically generated in the mid-latitudes and Southern Ocean. These waves occur year-round and are characterized by long periods and low wave heights with a southeasterly to southerly direction. Wind seas are locally generated, short period waves and wave height and direction can vary depending on the strength, duration, and direction of wind. These conditions are common in the summer months when daytime heating over the mainland causes strong onshore breezes from late morning to early evening. The two most energetic types of waves that affect the Gold Coast are East Coast Lows and tropical cyclones. East Coast Lows are intense low pressure systems typically generated off the south-east tip of Australia in the Tasman Sea. These typically occur in the austral autumn to winter months (April - August), with June being the most common. These storms can last several days and bring large waves, high winds, and rains to the coast. Tropical cyclones are typically generated in Northern Queensland in the Coral Sea and rarely propagate as far south as Southern Queensland. However, their effects are still present as a northerly swell influencing the coast during the late austral summer to autumn (January - March). The predominance of south-easterly waves results in a net longshore transport to the north (Splinter et al., 2010).

\section{Anthropogenic interference}

The Gold Coast Broadwater region has been exposed to several human interferences. Rapid development of the canal estates on the Gold Coast which was commencing in the 1960s; the construction of the Gold Coast Seaway and by-passing system in the 1980s with the aims of stabilising the entrance, maintaining a safe navigable channel, preventing shoreline erosion to the north and maintaining an adequate beach width to the south; and dredging several areas in the Broadwater with the aim of nourishing eroded beaches in the Gold Coast region and maintaining a safe navigable channel at the Seaway entrance. 


\section{Previous Analysis of Morphological Change}

According to an earlier analysis by Munday (1995), the Nerang River Inlet had a history of continual instability before its stabilisation. The inlet moved northwards, due to predominant south-easterly wave direction and the resulting net littoral sand transport to the north. Migration of the entrance has been recorded since early 1800's with rate of movement of up to 60m/year. Since the early 1900's the average inlet migration was 20-40 m/year (Munday, 1995). Between 1900 and 1970 approximately $10 \times 10^{6} \mathrm{~m}^{3}$ of sand accumulated in the Broadwater, as the inlet migrated northwards, at an average rate of $140000 \mathrm{~m}^{3} /$ year (Delft, 1976). In the early 1980's a decision was made to train the entrance. The Gold Coast Seaway stabilisation was completed in 1986 with two training walls. A new island, known as Wave Break Island, was created in order to reduce wave penetration and protect the western shore of the Broadwater. According to a report from Delft Hydraulics (Delft, 1970), because of the high magnitude of the northerly longshore drift on the Gold Coast any scheme to stabilise the entrance would require commitment to artificial sand bypassing across the entrance. The bypassing plant was also completed in 1986.

In the seven years after the new inlet was opened (November 1985- November 1992), the new ebb-delta grew approximately $3.4 \times 10^{6} \mathrm{~m}^{3}$. This made the total volume of the ebb-delta system almost $12 \times 10^{6} \mathrm{~m}^{3}$ above a normal beach the profile (assuming no entrance). During this period the ebb-delta crest deepened to about -6.5 $\mathrm{m}$ below sea level, and prograded $550 \mathrm{~m}$ offshore and $200 \mathrm{~m}$ downdrift (Munday, 1995).

\section{Methods and data}

The effects of different variables on morphological changes in the Gold Coast Seaway is being studied over a period of time. Bathymetry measured by Queensland Transport on an approximate annual basis in the Seaway vicinity was obtained and plotted. Changes in bathymetry were then determined between surveys. The quantity and nature of the morphological change is related to the changes that have occurred in the environmental and anthropogenic drivers between surveys.

\section{Offshore wave data}

Offshore wave characteristics are estimated every 6 hours using global wind-wave models such as the European Centre for Medium-Range Weather Forecasts (ECMWF) 40 year wave re-analysis (ERA-40) or the National Oceanographic and Atmospheric Administration (NOAA) WaveWatch III (WWIII). ERA-40 wave data is used in this research, since it is the longest, directional wave record available in this area. Caires and Sterl (2005) noted that the original ERA-40 model (1958 - 
2001) underestimated large waves compared to measured data and applied a correction factor to the ERA-40 wave heights resulting in a corrected data set known as the C-ERA-40. Here the C-ERA-40 (1958 - 2001) (Caires and Sterl, 2005) and ERA-Interim (1989 - present) data sets which was extracted in Splinter et al. (2010) research from grid point coordinates $(154.5,-28.5)$ located roughly $122 \mathrm{~km}$ south east from the Gold Coast Seaway (Figure 1) is used .

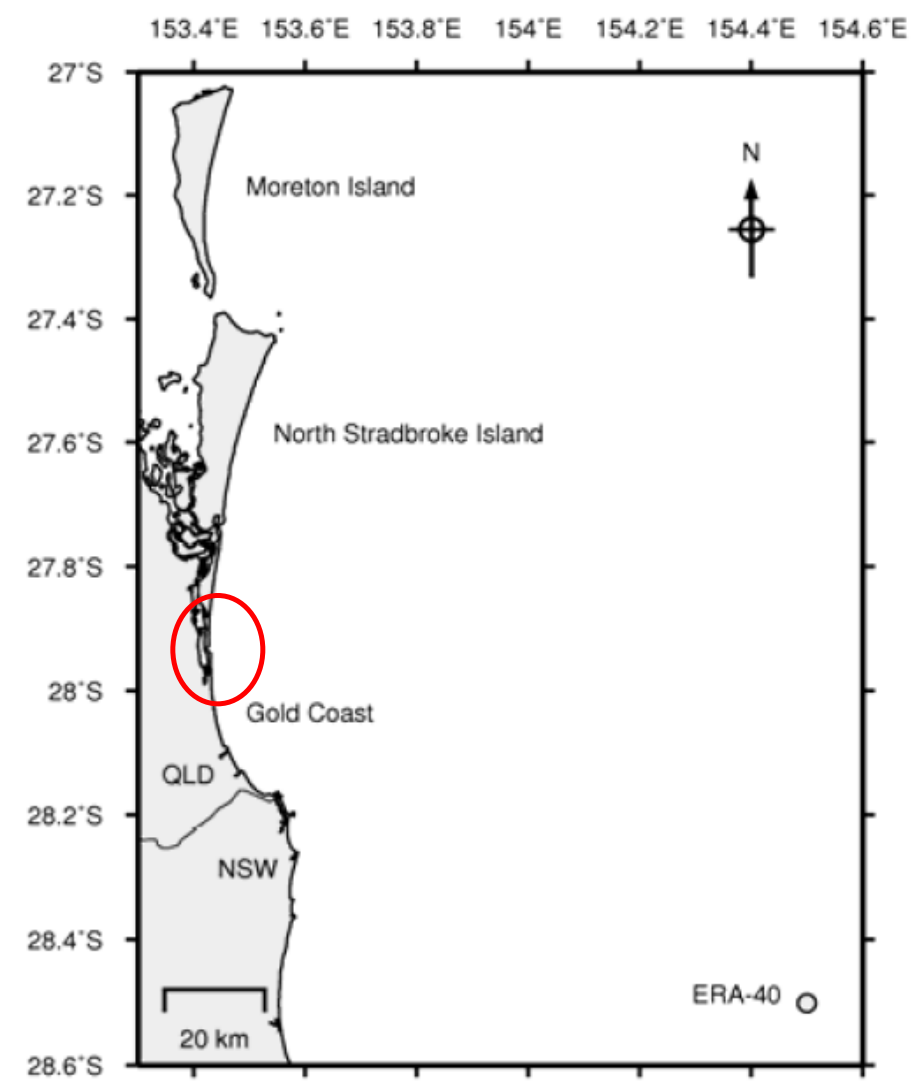

Figure1: Location of study area, Gold Coast. ERA-40 grid point where wave data is extracted from is given at bottom right.

Since the data available from C-ERA-40 and the ERA-Interim in the overlapping period does not completely match together Splinter et al. (2010) used over-lapping time series between the initiation of the ERA-Interim reanalysis to combine data sets and the C-ERA-40 data sets (number of comparison points=18,992) to determine a non-linear correction factor for the ERA-Interim wave heights using a Generalized Additive Model (GAM) technique (Splinter et al., 2010). Therefore, the final wave data that is used in this research was C-ERA-Interim. 


\section{Surveying, Volume of sand bypassing and dredging data}

Surveying data, dredging and volumes of sand bypassing was provided by Queensland Transport. The survey data is from 2000 up to 2011. The reference datum for various surveys differ as does the aerial extent of the surveys. A full analysis of all surveys will be undertaken in the future, but for the purposes of this preliminary assessment of short-term changes in morphology, along consistent data from 2004 onward will be used.

\section{Bypassing data}

Volume of bypassing is available in weekly, monthly and yearly basis. Therefore, from the available data the amount of bypassing for the mentioned time intervals is calculated. The result is as follows:

Table1. Data from Gold Coast Seaway sand bypass based on monthly record (Ref: Gold Coast Region Maritime Safety Queensland | Department of Transport)

\begin{tabular}{|c|c|c|}
\hline \multicolumn{2}{|c|}{ Date } & \multirow{2}{*}{ Volume Pumped $\left(\mathrm{m}^{3}\right)$} \\
\hline From: & To the end of: & \\
\hline Jan-04 & Jun-04 & 261,326 \\
\hline Jul-04 & Jun-05 & 659,448 \\
\hline Jul-05 & Mar-07 & $1,184,508$ \\
\hline Apr-07 & Jul-08 & $1,033,590$ \\
\hline Jul-08 & May-09 & 542,445 \\
\hline Jun-09 & Mar-11 & $1,025,410$ \\
\hline
\end{tabular}

\section{Dredging Data}

The Dredging data available for this period is shown in Table 2. As can be seen the amount of dredging in the channels is not significant in terms of the morphological evolution of Ebb-tidal delta, so this was neglected in the analysis at this stage.

Table2. Volume of Dredging in The Gold Coast Broadwater since 2004-2009

\begin{tabular}{|c||c||c||}
\hline Financial Year & Channel Name & $\begin{array}{c}\text { Volume of Dredging } \\
\mathbf{( m}^{\mathbf{3}} \mathbf{)}\end{array}$ \\
\hline \hline $2008 / 09$ & North Channel & 12,383 \\
\hline $2008 / 09$ & Canaipa Passage & 29,461 \\
\hline $2008 / 09$ & Coomera River Channel & 33,430 \\
\hline $2008 / 09$ & West Crab Island Channel & 21,284 \\
\hline $2008 / 09$ & North Channel & 31,560 \\
\hline
\end{tabular}




\section{Results}

Since the surveying has been done at various months of each year, and many of them do not include all the investigated area, the variance of bathymetry between the applicable surveying data was calculated. Therefore, all other effective factors which may influence morphology were calculated for the periods that the variance of surveying data was calculated.

\section{Bathymetric changes}

Morphological change can be expressed in terms of volumes of erosion or deposition in a particular area, or in terms of changes in the configuration of the morphological features. In this case the distance offshore to the crest of the delta is chosen as a measure of delta configuration.

In order to calculate the volumes of deposition and erosion the morphological changes of each interval was subdivided to areas of erosion and accretion as you can see in (Figure 2).

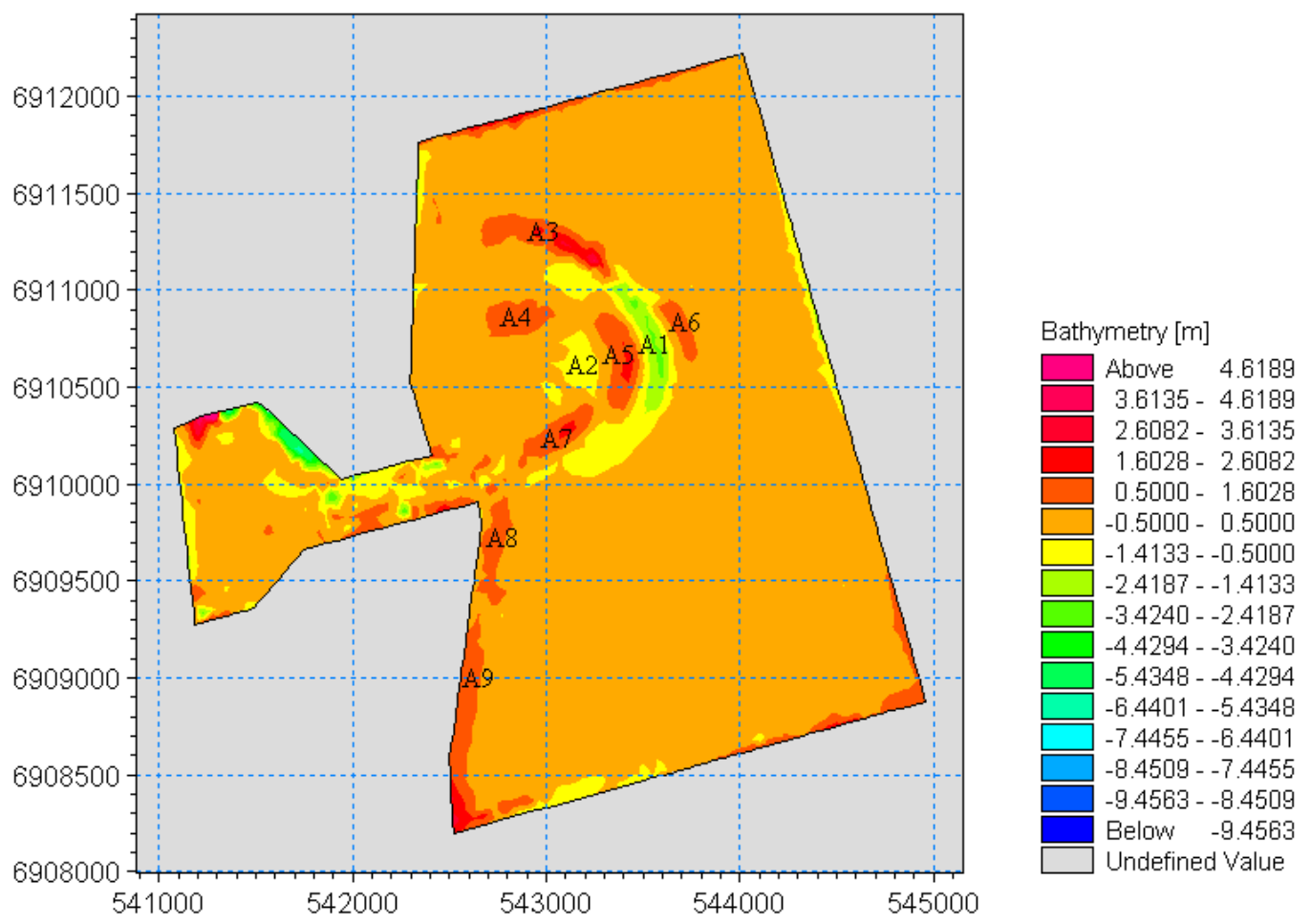

Figure 2: Morphological changes ( $\Delta D)$ from April 2007 to August 2008 (Positive numbers means accretion and negative numbers means erosion occurred)

The results for the volumetric analysis are indicated in Table3. 
Table3. Total volume of sedimentation (deposition/erosion) in the study area

\begin{tabular}{|c|c|c|c|c|c|c|}
\hline 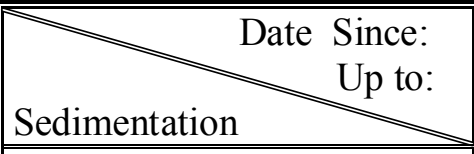 & $\begin{array}{l}\text { Jan } 2004 \\
\text { July } 2004\end{array}$ & \begin{tabular}{|l|} 
July 2004 \\
July 2005
\end{tabular} & $\begin{array}{l}\text { July } 2005 \\
\text { Apr } 2007\end{array}$ & $\begin{array}{l}\text { Apr } 2007 \\
\text { Aug } 2008\end{array}$ & \begin{tabular}{|l|} 
Aug 2008 \\
June 2009
\end{tabular} & $\begin{array}{c}\text { June } 2009 \\
\text { March } \\
2011 \\
\end{array}$ \\
\hline Total volume of erosion $\left(\mathrm{m}^{3}\right)$ & $-483,900$ & $-101,612$ & $-142,637$ & $-355,071$ & $-415,106$ & $-902,306$ \\
\hline $\begin{array}{l}\text { Total volume of deposition } \\
\left(\mathrm{m}^{3}\right)\end{array}$ & $1,400,61$ & 319,091 & 530,558 & 445,962 & $1,223,803$ & 510,091 \\
\hline $\begin{array}{l}\text { Net volume of sedimentation } \\
\left(\mathrm{m}^{3}\right)\end{array}$ & $-343,839$ & 217,480 & 387,921 & 90,891 & 808,698 & $-392,215$ \\
\hline \multicolumn{7}{|c|}{ Sedimentation in the seaway Ebb-delta (at the Inlet mouth and to the North) } \\
\hline $\begin{array}{l}\text { Total volume of erosion in } \\
\text { delta }\left(\mathrm{m}^{3}\right)\end{array}$ & $-294,916$ & $-56,469$ & $-142,637$ & $-355,071$ & $-415,106$ & $-491,561$ \\
\hline $\begin{array}{l}\text { Total volume of deposition in } \\
\text { delta }\left(\mathrm{m}^{3}\right)\end{array}$ & 99,410 & 164,307 & 500,263 & 326,524 & 626,248 & 510,091 \\
\hline $\begin{array}{l}\text { Net volume of sedimentation } \\
\text { in delta }\left(\mathrm{m}^{3}\right)\end{array}$ & $-195,506$ & 107,838 & 357,626 & $-28,547$ & 211,142 & 18,530 \\
\hline
\end{tabular}

\section{Wave Climate}

In order to assess changes in wave climate between surveys wave roses were drawn using MIKE Zero for the wave data sub-sets between morphological changes intervals (Figure 3). As it is shown in Figure 3 which is for one of the intervals, the dominant wave direction in this case and most of other sub-sets is from East and South-East, and wave height is mostly 1-3 meter.

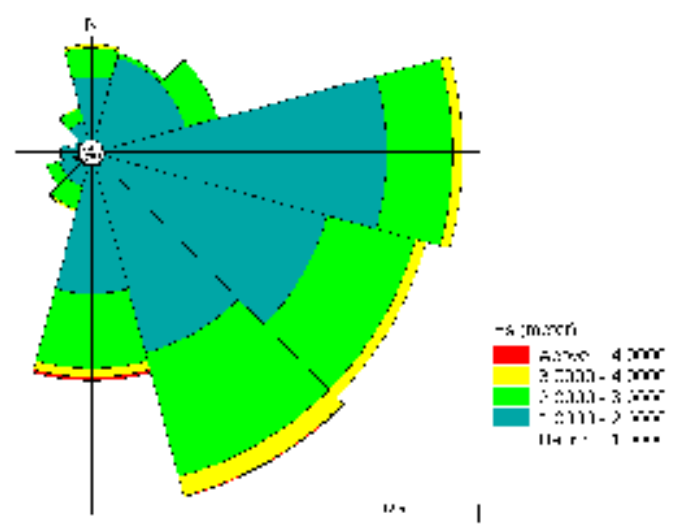

Figure 3: Typical Wave rose from June 2009-January 2011 


\section{Delta Crest Movement}

As surveying data was not available on an annual basis, analysis was based on the times that surveying were done. Surveying data was imported to MIKE21 to generate a bathymetry map for each survey. The crest of delta seaward edge (at $-6 \mathrm{~m}$ depth) is chosen as a reference line for analysing the crest of delta movement (Figure 4).

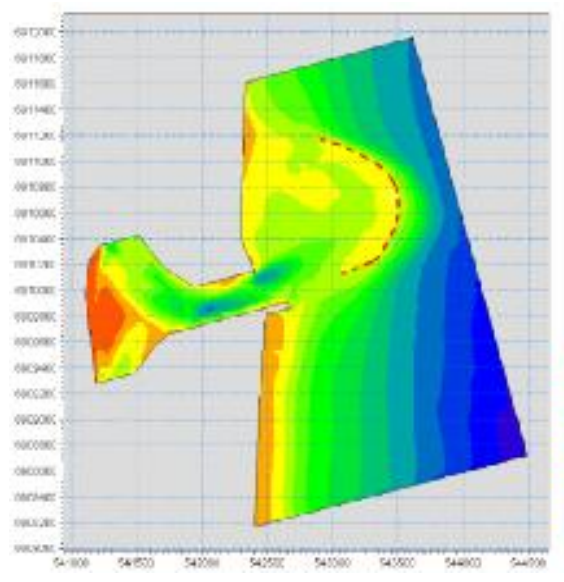

(a)

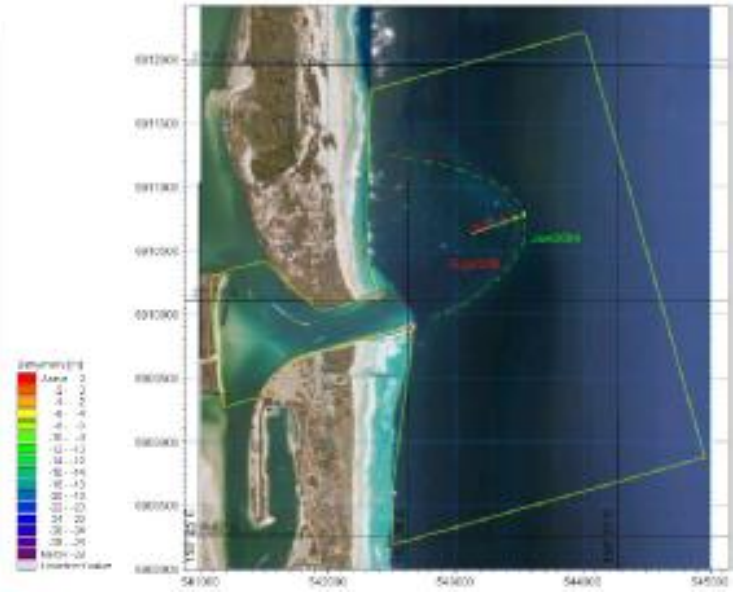

(b)

Figure 4: (a) Bathymetry map established based on surveying data of Queensland Transport in July 2004, Crest movement analysis based on dashed line which is the edge of -6 m depth. (b)Crest movement between Jan 2004 and Aug 2008 (sample)

The result of crest movement (horizontal) analysis is displayed in Table 3, positive numbers indicate seaward/to the east movement.

Table3. Approximate ebb-delta crest movement

\begin{tabular}{|c|c|c|}
\hline \multicolumn{2}{|c|}{ Date } & \multirow{2}{*}{ Ebb-delta crest movement (to the ocean/horizontal)(m) } \\
\hline From: & To: & \\
\hline Jan-04 & Jul-04 & -26 \\
\hline Jul-04 & Jul-05 & $\sim 0$ \\
\hline Jul-05 & Apr-07 & +86 \\
\hline Apr-07 & Aug-08 & -104 \\
\hline Aug-08 & Jul-09 & -78 \\
\hline Jul-09 & Mar-11 & +117 \\
\hline
\end{tabular}


January 2004-July 2004
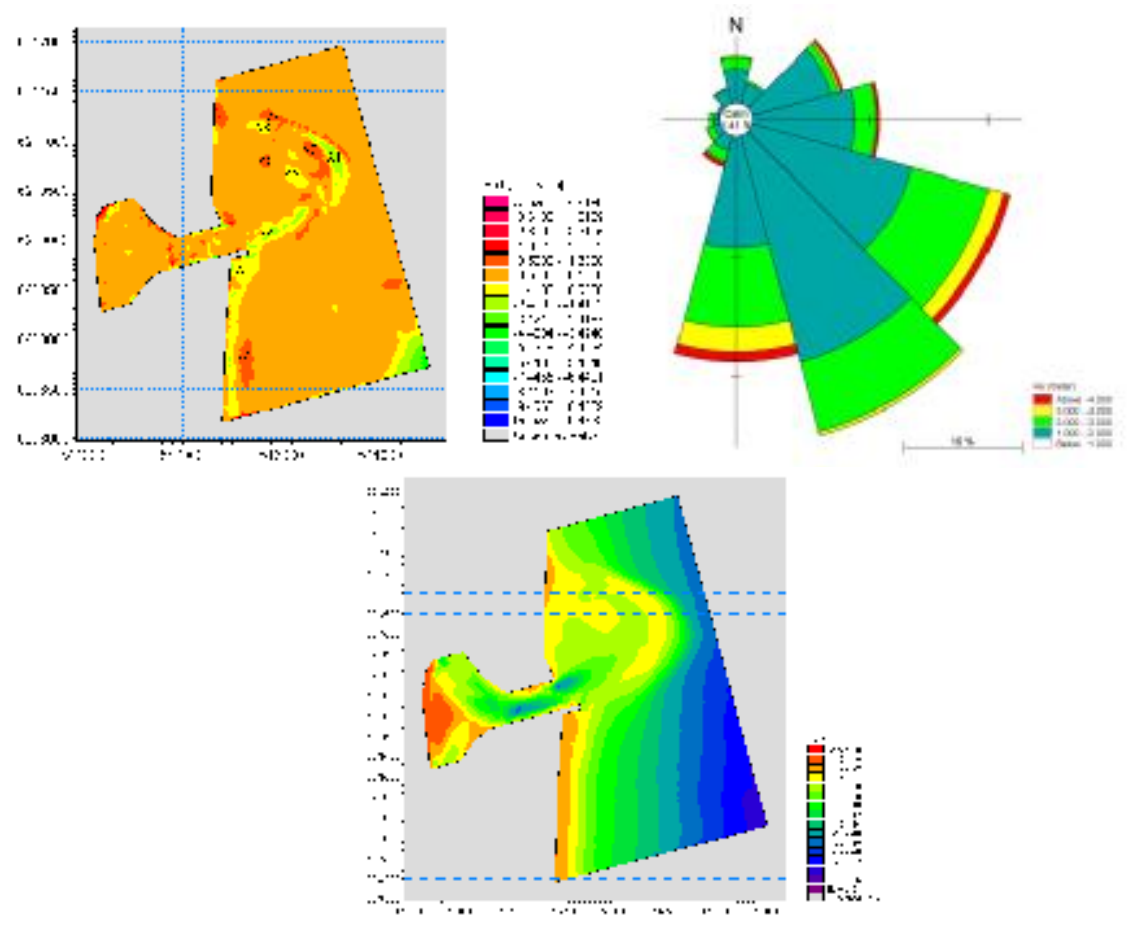

Figure5: (from left to right)-(a)bathymetry changes from Jan2004-July2004,(b)Wave rose in this period, (c)Bathymetry map of Gold coast Seaway in July 2004

Data shows that during this period erosion was dominant, and about $200,000 \mathrm{~m}^{3}$ of the ebb-tidal delta was eroded, and since the crest of delta was eroded, there was about $26 \mathrm{~m}$ shoreward movement of the crest (to the west). On the other hand, about $260,000 \mathrm{~m}^{3}$ of sand was pumped through the bypassing system to the North during this period, which would is equivalent to an annual rate of $520,000 \mathrm{~m}^{3} /$ year which is close to the assumed average net longshore transport rate.

\section{July 2004- July 2005}

It is notable that there is approximately no horizontal movement of the crest of delta from July 2004-July 2005. It could be a sign of equilibrium in the system during a complete yearly cycle of wave climate during which no significant storms occurred. However, some deposition occurred within the delta of about $107,000 \mathrm{~m}^{3}$, with approximately $660,000 \mathrm{~m}^{3}$ of sand pumped. This rate of pumping is close to the average pumping rate monitored until recently. 

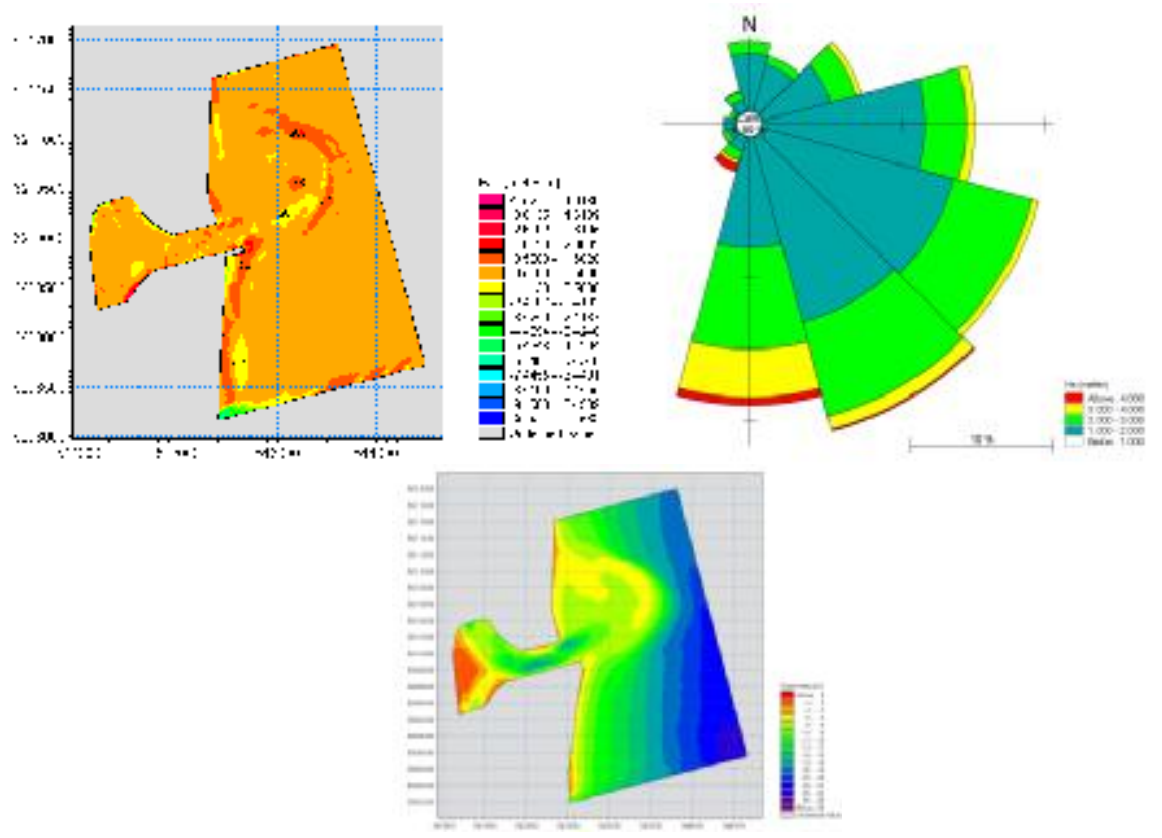

Figure6: (from left to right)-(a)bathymetry changes from July2004July2005,(b)Wave rose in this period, (c)Bathymetry map of Gold coast Seaway in July 2005

July 2005-Apr 2007
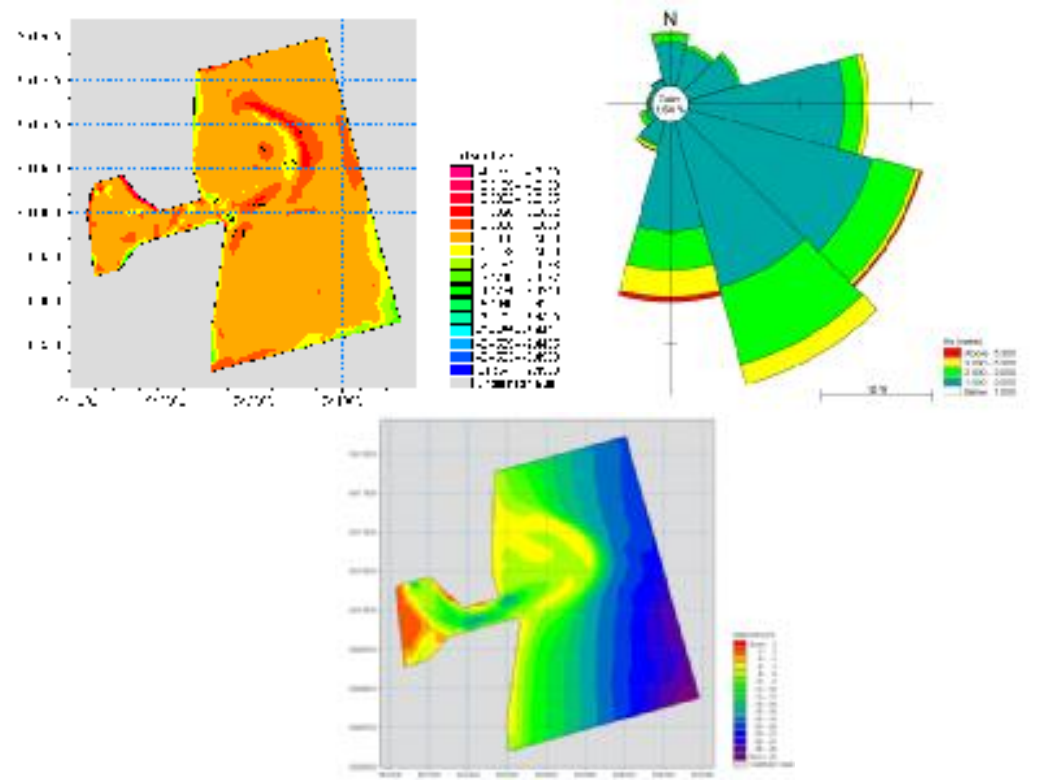

Figure7: (from left to right)-(a)bathymetry changes from July2005-Apr2007,(b)Wave rose in this period, (c)Bathymetry map of Gold coast Seaway in Apr 2007 
During this 21 months period a large amount of deposition occurred at the toe of delta which lead to about $86 \mathrm{~m}$ progradation of crest farther offshore. The net amount of deposition was about $360,000 \mathrm{~m}^{3}$, while about $1,190,000 \mathrm{~m}^{3}$ sand had been pumped $\left(672,000 \mathrm{~m}^{3} /\right.$ year$)$.

\section{Apr 2007-Aug 2008}
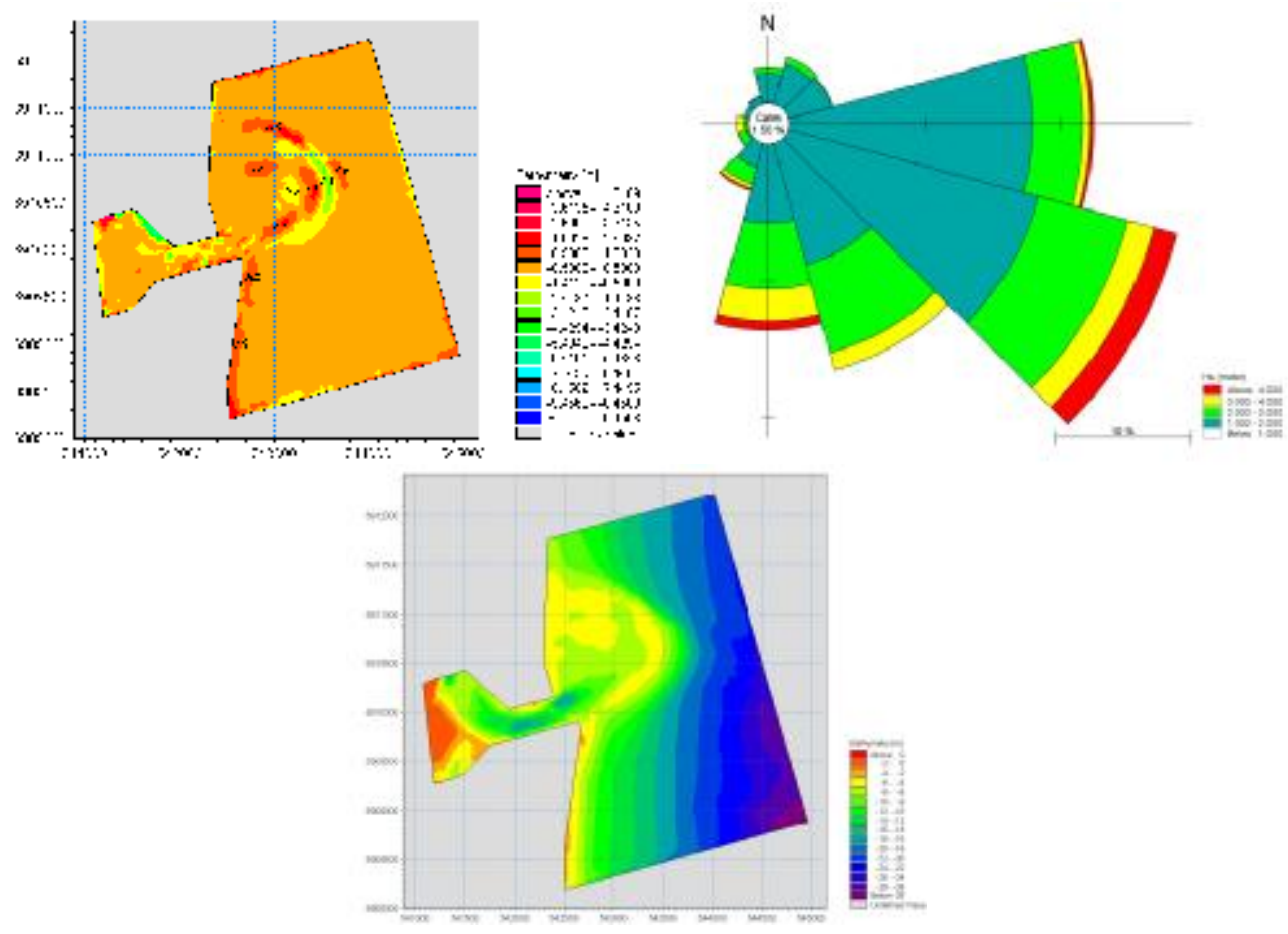

Figure8: (from left to right)-(a)bathymetry changes from Apr2007-Aug2008,(b)Wave rose in this period, (c)Bathymetry map of Gold Coast Seaway in Aug 2008

In this period the deposition that was evident in the toe of delta and caused its progradation in previous time interval is eroded, which result in $104 \mathrm{~m}$ movement of the crest shoreward (very close to the place that it had in July 2004 and July 2005) (Figure8). Moreover, it seems that the sand which is eroded from the crest is deposited farther inside the delta, since the approximate net amount of sedimentation in the delta is not large - approximately $29,000 \mathrm{~m}^{3}$ erosion. This change is most likely due to the more easterly wave climate compare with the previous few years. A direct shore perpendicular wave direction would act to restrict the seaward growth of the delta. The amount of sand that pump during this time was $540,000 \mathrm{~m}^{3}$ which is equal to $648,000 \mathrm{~m}^{3} /$ year, that is approximately equal to the rate of sand pumped during July 2004-July 2005. 
Aug 2008- June 2009
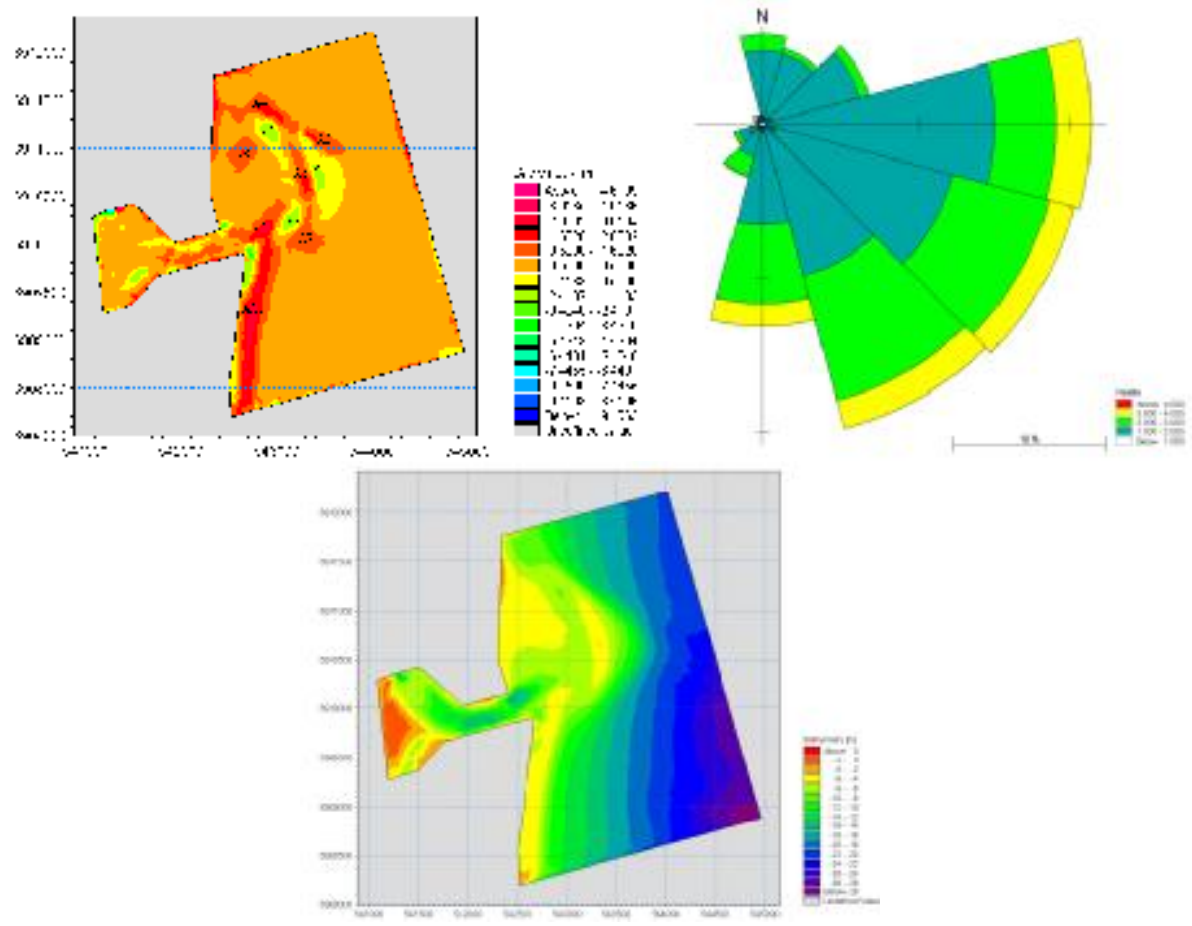

Figure9: (from left to right)-(a)bathymetry changes from Aug2008June2009,(b)Wave rose in this period, (c)Bathymetry map of Gold Coast Seaway in June 2009

In this period significant storms hit the Gold Coast region including Tropical Cyclone Hamish early in 2009 and the East Coast Low (ECL) in May 2009. The ECL in particular caused significant shoreline erosion in the vicinity of the Seaway, with a large storm bar forming offshore. The storm also scoured the crest of ebbdelta resulting in a shoreward movement of around $80 \mathrm{~m}$, and a longshore elongation of the delta. The amount of sand pumped during this interval was $540,000 \mathrm{~m}^{3}$, while the approximate net volume of sediment added to the delta was about $210,000 \mathrm{~m}^{3}$. As can be seen in Figure 9a and c), it could be also concluded that the erosion in area A2 and A3 (see Fig. 9a) and therefore accretion in area A4 is the influence of both the strong wave induced longshore transport and the cross-shore sand movement due to the dominant easterly wave direction.

\section{June 2009- March 2011}

By March 2011 most of the sediment which was deposited by the 2009 storms has eroded back (Figure 10). Analysis of the bathymetry changes shows that the total delta and near shoreline morphology tended to return to the situation that it had 
before the 2009 storms, since the crest of delta moved offshore about $117 \mathrm{~m}$. The total deposition and erosion within the delta was very low - about $190,000 \mathrm{~m}^{3}$ which could be an indication that the morphology may be reaching an "equilibrium". The volume of sand pumped by the bypassing system was around $103,000 \mathrm{~m}^{3}(588,000$ $\mathrm{m}^{3} /$ year).
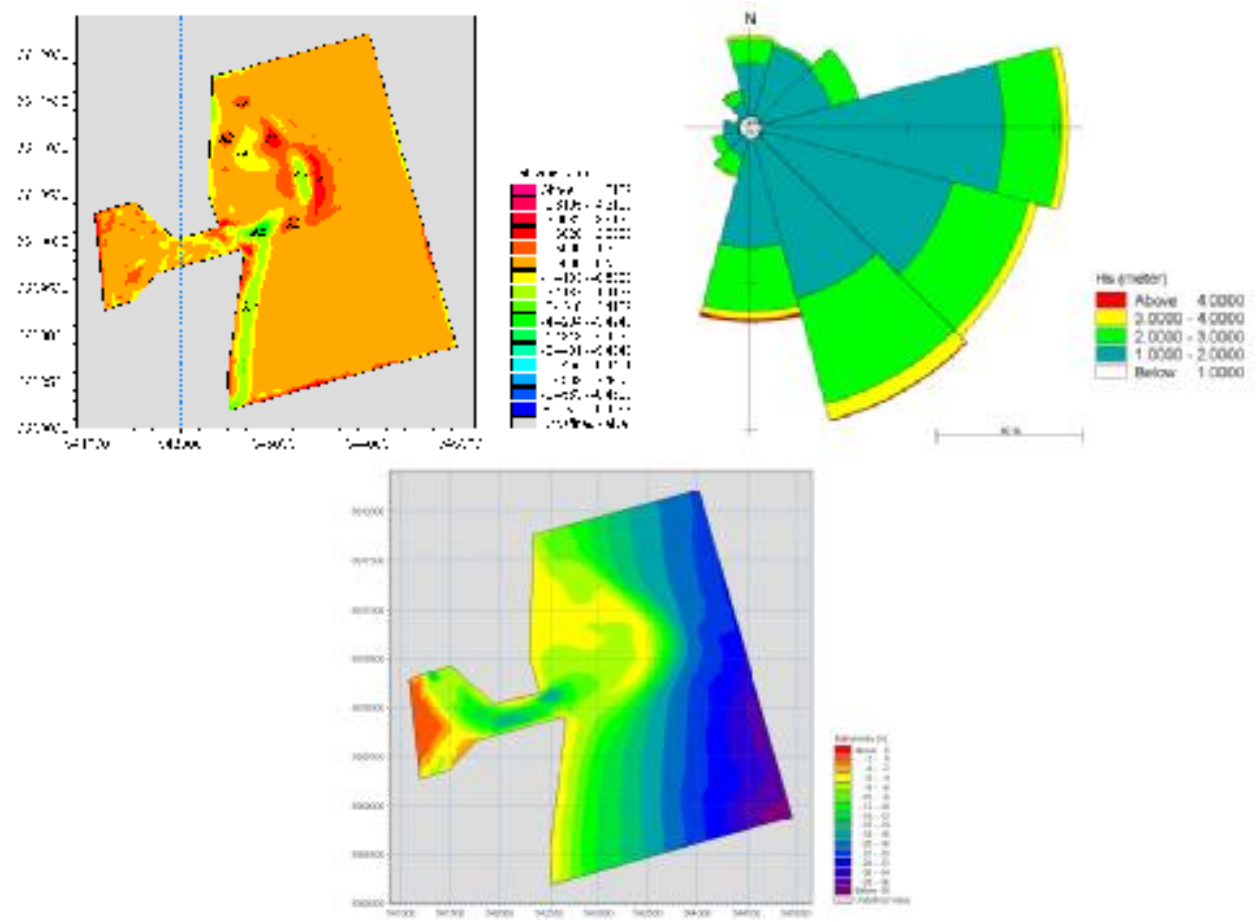

Figure 10: (from left to right)-(a)bathymetry changes from June2009March2011,(b) Wave rose in this period, (c)Bathymetry map of Gold Coast Seaway in March 2011

\section{Conclusion}

The bathymetric historical data from 2004 to 2011 was collected and the trend of morphological changes through these years mapped out. According to the analysis it seems that the Seaway ebb-tidal delta may be reaching a point of equilibrium between the amount of longshore and cross-shore sand supply, and volume of bypassing during these years. The major parameter that caused sudden changes in the morphology was large storm activity, with gradual recovery of the ebb-delta volume and configuration. 


\section{References}

Caires, S. and Sterl, A., 2005. A New Nonparametric method to Correct Model Data: Application to Significant Wave Height from the ERA-40 Re-Analysis. Journal of Atmospheric and Oceanic Technology, 22: 443-459.

Chapman, D.E.M., 1981. Coastal erosion and the sediment budget, with special reference to the Gold Coast, Australia. Coastal Engineering, 4: 207-227.

D'Agata, M. and Tomlinson, R., 2004. Investigation of Ebb Tidal Deltas using a Numerical Model at the Moveable Bed Physical Model Scale, Research Report 27, Griffith Centre for Coastal Management CRC for Coastal Zone Estuary \& Waterway Management.

Delft, 1970. Gold Coast, Queensland Australia - Coastal erosion and related problems, Report 257, Delft Hydraulics Laboratory, The Netherlands.

Delft, 1976. Nerang River Entrance Stabilisation, Report on Model Investigation, Delf hydraulic Report M1259.

McCauley, E.K., 1997. The evolution of Jumpinpin Inlet, Griffith University, Gold Coast.

Mirfenderesk, H. and Tomlinson, R., 2008. Observation and Analysis of Hydrodynamic Parameters in Tidal Inlets in a Predominantly Semidiurnal Regime. Journal of Coastal Research, 24(5): 1229-1239.

Munday, D., 1995. Coastal response to the Nerang River inlet stabilisation, Gold Coast, Queensland, Australia, Queensland University of Technology, Brisbane.

Patterson, D.C., 2007. Sand Transport and Shoreline Evolution, Northern Gold Coast, Australia. Journal of Coastal Research, SI 50: 147 - 151.

Polglase, R.H., 1987. The Nerang River Entrance Sand-Bypassing System, 8th Australian Conference on Coastal Ocean Engineering, pp. 222-226.

Sennes, G., Castelle, B., Bertin, X., Mirfenderesk, H. and Tomlinson, R.B., 2007. Modelling of the Gold Coast Seaway tidal inlet, Australia. Journal of Coastal Research, 50: 1086 - 1091.

Splinter, K.D., Golshani, A., Stuart, G. and Tomlinson, R., 2010. Spatial and temporal variability of longshore transport along Gold Coast, Australia, ICCE.

Voisey, C., 2004. Moveable Bed Physical Modelling of Ebb Delta Growth Characteristics, Research Report 25, Griffith Centre for Coastal Management CRC for Coastal Zone Estuary \& Waterway Management.

WRL and GCCM, 1998. Numerical Modelling of Sediment Movement and Budget at Seaway, Water Research Laboratory in association with Griffith University for GCCC, Gold Coast 